\title{
Oropharyngeal (p16-Negative) Cancer Pathologic Distant Metastasis TNM
} Finding v8

National Cancer Institute

\section{Source}

National Cancer Institute. Oropharyngeal (p16-Negative) Cancer Pathologic Distant Metastasis TNM Finding v8. NCI Thesaurus. Code C132981.

A pathologic finding about one or more characteristics of oropharyngeal (p16-negative) cancer, following the rules of the TNM AJCC v8 classification system as they pertain to distant metastases. 